\title{
Public Opinion about Climate Change in United States, Partisan View and Media Coverage of the 2019 United Nations Climate Change Conference (COP 25) in Madrid
}

\author{
Antonio Castillo Esparcia * and Sara López Gómez * (D) \\ Audiovisual Communication and Advertising, Faculty of Communication Sciences, University of Malaga, \\ 29010 Málaga, Spain \\ * Correspondence: acastilloe@uma.es (A.C.E.); saralogo22@uma.es (S.L.G.); \\ Tel.: +34-952136609 (A.C.E.); +34-689377537 (S.L.G.)
}

Citation: Castillo Esparcia, A.; López Gómez, S. Public Opinion about Climate Change in United States,

Partisan View and Media Coverage of the 2019 United Nations Climate Change Conference (COP 25) in Madrid. Sustainability 2021, 13, 3926. https://doi.org/10.3390/su13073926

Academic Editor: Christopher Robin Bryant and Stewart Barr

Received: 3 February 2021

Accepted: 27 March 2021

Published: 1 April 2021

Publisher's Note: MDPI stays neutral with regard to jurisdictional claims in published maps and institutional affiliations.

Copyright: (C) 2021 by the authors. Licensee MDPI, Basel, Switzerland. This article is an open access article distributed under the terms and conditions of the Creative Commons Attribution (CC BY) license (https:// creativecommons.org/licenses/by/ $4.0 /)$.
Abstract: The research examines the news on climate change in different media, through the analysis of agenda setting and framing, in the context of a construction of media discourse. The role of the media has been relevant in the symbolic struggle of climate change images. The polarized public opinion on climate change in the USA, which has led the Trump government to withdraw from the Paris Agreement, as well as the revocation of environmental policies, is analyzed by the coverage that media with Republican and Democratic political tendencies gave to the climate crisis during the 12 days of the 2019 Climate Summit. The 189 news articles broadcast by Fox News, Breitbart, CNN, and the New York Times were identified, analyzed, and contrasted. The results reveal that media with a Republican political tendency were the only ones that broadcast denial news of climate change. Breitbart reported the largest number of news items throughout the sample, mostly denialists, at $71 \%$, using tactics related to the spectacularization of the climate phenomenon, ad hominem attacks on ecologists and politicians, the connection between environmental initiatives and "eco-fascism" or the "radical left", as well as use of the half-truth fallacy and questionable sources associated with the fossil fuel industry. Fox News practically did not address the issue during the summit. The Democratic political tendency media did not report any kind of denial news; their information and opinions communicated environmental initiatives and climate change consequences.

Keywords: climate emergency; public opinion; climate skepticism; COP25 2019 Madrid; United States Media; Democratic party; Republican party; Fox News; CNN; New York Times; Breitbart

\section{Introduction}

The climate emergency is one of the great challenges of the 21st century; the IPCC's (Intergovernmental Panel on Climate Change) reports warn that human activities have already caused global warming of approximately $1.0^{\circ} \mathrm{C}$ above pre-industrial levels, and that this will last for centuries to millennia and will continue to cause further long-term changes in the climate system. The repercussions expected are those such as the loss and extinction of species, an increase in diseases like malaria and dengue fever, a decrease in the availability of food and drinking water, an increase in precipitation, and an increase in the probability of severe events including droughts, hurricanes, heat waves, and floods [1].

The Paris Climate Agreement, approved in 2012 and ratified in 2015 by 195 nations, aims to promote research and development of renewable energy, supporting economic investment in developing countries in order that they can better adapt to the energy transition, with innovative technologies that allow them to mitigate the consequences of climate change, keeping the increase in global temperature below $2.0^{\circ} \mathrm{C}$ and reducing $\mathrm{CO}_{2}$ emissions well before 2030 [2]. However, in June 2017, US President Donald Trump, as part of his electoral promise, announced the withdrawal of the Paris Agreement, stating that he was committed to the economic interests of the nation and the agreement, in contrast, 
favored countries like China, punishing the US economy [3]. The United States is the second largest emitter of $\mathrm{CO}_{2}$ in the world, surpassed only by China and followed by the European Union, India, Russia, and Japan [4]. For this reason, his decision to withdraw from the Agreement has generated a number of national and international tensions, as well as uncertainty about the implementation of the proposed reductions.

Studies from Stanford University about public opinion on climate change in the United States indicate that in general terms Americans are increasingly aware of this problem. The percentage of people who say that the earth's temperature has increased has risen from $43 \%$ in 1997 to $59 \%$ in 2018 . However, they point out that the partisan gap has increased from 13\% in 1997 to 32\% in 2018 [5]. The polarization makes consensus on climate science difficult and locks the climate change debate and actions to curb it into a partisan dispute that slows and complicates climate policy makers. From this perspective, it is worth asking how this partisan gap in public opinion is accentuated, the possible incidence of the media in the polarization of these discourses, and, in short, if it is possible to distinguish substantial differences in the informative treatment of climate change in media with Republican and Democratic political tendencies.

The role of the media has been relevant in the symbolic struggle of climate change images [6-15]. In this context, an analysis of the coverage of the 2019 Climate Summit from December 2 to December 13 by the Democratic and Republican oriented media is proposed. The selection of the media was justified according to the 2019 report of the Reuters Institute for the Study of Journalism [16], which identifies the media with greater tendency to a certain political current in the country.

\section{Literature Review}

\subsection{Relationship between Economic Lobbies and Climate Change Denial}

The tactics of the tobacco's industry lobbies that generated billions of revenues in U.S. and affected public health have been replicated by the climate change denialist lobbies, implanting confusion and doubt through controversy to destabilize the scientific consensus. When lobbyists are affected by greenhouse gas reduction proposals, they try to confuse and mislead the public, especially policy makers, in order to delay and avoid legislation on the issue, presenting themselves as environmentally responsible, but with questionable solutions such as "clean" coal [17]. These elites form a whole network of networks, mobilizing resources in order to influence the development of environmental policy [18]. The elites first suppress information that may threaten their interests, then organize and fund institutions to produce climate science denialist information, then subsidize various experts who are willing to discredit research that is potentially damaging to their cause, and finally attempt to exercise dominance in both knowledge management and the selection of information that is classified as climate science knowledge and that is not.

The 2011 report by the Global Warming Policy Foundation [19] points out that nine of the ten most cited climate change skeptics have links to ExxonMobil-funded entities. Organizations such as Koch Industries, the second largest company in the United States, with more than 10 conglomerates dedicated to the manufacture, refining, and distribution of oil, chemicals, fibers, energy, polymers, minerals, fertilizers, and paper, as well as chemical technology equipment and others, have spent at least $\$ 88$ million on the denial of climate change science since 1997 [20,21]. In her 2016 book, Dark Money: The Hidden History of the Billionaires Behind the Rise of the Radical Right, the research journalist Jane Mayer explores in depth the influence of the fossil and coal lobby on US politics, indicating that the millions of dollars in funding to organizations including Americans for Prosperity or the Heritage Foundation, libertarian/conservative political advocacy think tanks, through trusts such as the Donors Trust and Donors Capital Fund, ensure taxpayers' anonymity in their donations [22]. Mayer assures that the Trump administration and the Republican Party are closely linked to the fossil fuel industry, and that President Trump himself, Vice President Mike Pence, and the former administrator of the U.S. Environmental Protection Agency, Scott Pruitt, are linked to petrochemical magnate Koch Industries. Mayer details 
that the purchase of influence of the fossil energy lobby on the country's politics has been made by corporate lobbying, nonprofit investments with political overtones, and contributions to state and local election campaigns. About these last ones, she explains that the financing is done mainly to small campaigns in order not to call the attention of the press. In Texas, for example, the petrochemical conglomerate supported 74 different candidates in 2016 [22] (p. 12).

\subsection{Conservative Think Tanks (CTT) and the Skeptical Climate Change Strategy}

Conservative think tanks, or CTTs, are central players in the so called "denial machine" of climate science. Analysis of more than 141 environmentally skeptical books in English, published between 1972 and 2005, reveals that 92\% of these were linked to conservative think tanks [23-26] such as the Heartland Institute, a conservative and libertarian US public policy group, whose statements focus on the idea that studies on climate science are questionable and conventional climate science is oppressive. In this vein, climate skeptics are presented as "victims of orthodoxy" and as the true providers of "healthy" science [27] (p. 17). The anti-communist and fundamentalist discourses of the free market perceive the regulations of the government in private industry as a dangerous advance toward communism, and on this basis they support their arguments, calling the ecologists radical leftists [24,25].

These skeptical discourses have been defined by McKie as tactics of denial of responsibility: "climate change is happening, but humans are not the cause"; denial of harm or injury: "climate change cannot cause harm, or if it did, the consequences would be positive"; denial of the victim: "there are no victims of climate change, or if there were, they deserve to be victims"; condemnation of the condemner: "climate change research is distorted by scientists, and manipulated by the media, politicians and environmentalists"; and appeal for greater loyalty: "economic progress and development are more important than preventing climate change" [28] (p. 8). Interdisciplinary studies [23,29,30] explore some of the social, political, and economic factors, as well as cultural and psychological characteristics, that have influenced the adoption of these beliefs, characterizing ultra-conservative white men as significantly more likely than other Americans to support these views.

\subsection{Climate Change Coverage in the Media}

The main difficulty in the communication of climate change is the transmission of existence and urgency sense of what has been called a "temporary environmental problem" [31]. This has led to an information bias in the coverage of the climate emergency, derived, among other things, from the constant adherence to journalistic standards, which determine the selection and the content of the news [32] (p. 1192). Dramatization: News dramas emphasize the crisis over continuity and minimize complex information about politics and the power bases behind the central characters. Novelty: "it is not news unless it is new", which results in a "problem of the month syndrome", and because it is a constant problem, it is not perceived as novelty. Authority: Journalists tend to consult mainly, and sometimes only, governments, public officials, and business leaders (in the case of the United States, official sources have presented contrary positions to international scientific consensus). Balance: Thousands of the world's most reputable scientists argue for the existence of climate change, compared to a few dozen deniers, who have generally not published their skeptical claims in peer-reviewed journals. In this sense, balance is manifested as an exaltation of both positions, even if one is a minority in the scientific ecosystem, transmitting ultimately a sense of uncertainty $[33,34]$. People's active resistance to disturbing information makes climate skepticism possible. In people from rich nations, this behavior is especially present, because they do not perceive the effects of climate in their daily lives, conceiving climate action as a highly costly process for their lifestyles [35]. In virtual platforms such as Twitter, investigations related to climate change messages [36,37] reveal that users adapt to the dominant public opinion within the respective media, where the higher the degree of homogeneity of information, the lower the polarization on a given 
topic, in a sort of echo chamber that replicates information again and again from a single point of view.

In this sense, the presence in the media is a consequence of the communication strategies of political actors (parties and governments) and social actors (think tanks and lobbies), which seek to participate in the processes of agenda-setting and framing $[38,39]$. Thus, the role of the media has been essential in disseminating information. Media discourse on climate change has oscillated between two perspectives, as shown in Figure 1 below:

- Endogenous factors on the how, type, and why of ideas and images on climate change and an increasing presence of emotional discourses [7,40,41].

- Exogenous factors to the phenomenon, such as the politicization of public issues and media polarization [12,42].

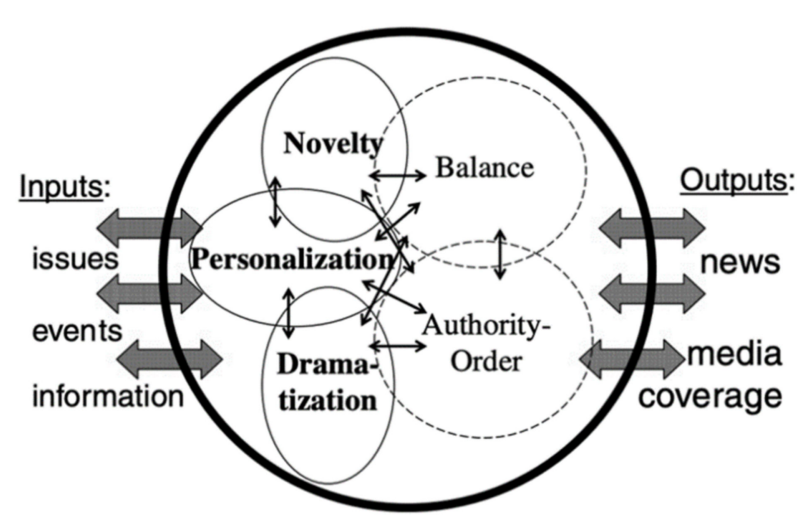

Figure 1. Interacting journalistic standards. This figure represents the public arena of media production, where journalistic standards interact. These complex and dynamic factors take place within and between, as well as in relation to, a broader context of political, social, cultural, and economic norms and pressures. Reprinted from ref. [32] (p. 1193).

This has created a strategic communication landscape in which many actors (scientists, politicians, think tanks, and lobbies) with scientific interests, but also with political interests, are involved [43]. This confrontation of interests brings richness to the discussion of the issue, but also confusion and biased information. Hence, many studies call for the need to provide rigorous and contrasted data and information [8-12,18].

These new strategic and self-serving narratives detract from the clarifying role of climate change and sometimes focus more on the storyteller than the information being conveyed, making the credibility of the message more akin to the values of the source than the content $[13,44]$.

\section{Materials and Methods}

\subsection{Media Selection}

The media selection was justified according to the 2019 report of the Reuters Institute for the Study of Journalism, which identifies the media outlets with the highest tendency to a certain political current in the country. As can be seen in Figure 2, with a Republican political tendency are Mail Online, Fox News, and Breitbart, and with a Democratic political tendency are NBC, CNN, the New York Times, Huffpost, and Occupy Democrats [16]. For these purposes, the media that have a significant participation in the digital environment, are approximately similar to each other, and regularly publish journalistic content, which excludes platforms as Occupy Democrats for being a Facebook page, were selected within this categorization. The final selection includes CNN (19\% participation), Fox News (19\% participation), the New York Times (17\% participation), and Breitbart ( $7 \%$ participation). 
CROSS-PLATFORM AUDIENCE MAP - USA

LEFT-RIGHT POLARISATION

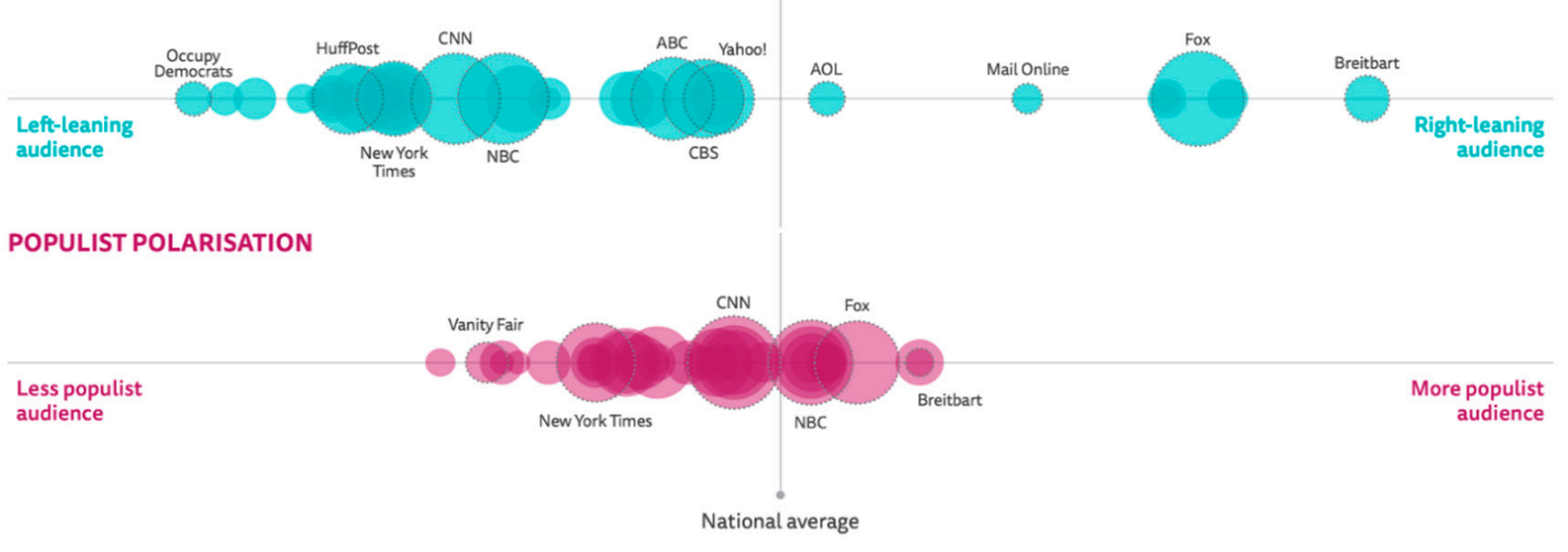

Q2_2019_1/2. Please indicate your level of agreement with the following statements: The people should be asked whenever important decisions are taken/Most elected officials don't care what people like me think. Q1F. Some people talk about 'left', 'right', and 'centre' to describe parties and politicians. With this in mind, where would you place yourself on the following scale? Q5A/B. Which of the following brands have you used to access news offline/online in the last week? Base: Total sample: UK=2023, USA = 2012.

Figure 2. United States multiplatform audience map: left and right polarization and populist polarization. Reuters Institute, 2019 Digital News Report. Reprinted from ref. [16] (p. 44).

\subsection{Data Collection Method}

A mixed methodology was proposed, implementing quantitative techniques in the analysis of news categories and qualitative techniques in the study of their discursive construction. The information was collected in two moments. First, a standardized filtering was implemented in the web portals of each media, using the keyword search "2019 Climate Summit COP 25", specifying in the search filters, date, and type of content, opened to articles and videos. Afterwards, it was verified that the results obtained in the platform of each media coincided with the results shown in the web search, individually and by date, corroborating that it was indeed a news item related to climate change. The news item had to fulfill one or more of these criteria to be selected into the sample: mention the Climate Summit; address phenomena related to climate change, such as protests, public policies, private sector initiatives, and extreme weather events including floods, droughts, and fires; make reference to scientific studies or reports concerned with climate science or causes or consequences of climate change; or include events or statements by politicians, institutions, members of the fossil and/or energy industry, activists or others in relation to climate change, global warming or similar. A template was used to analyze the different variables: typology of the news, tagging, terminology, sources used, position of the news, mention of the United States' withdrawal from the Paris Agreement, mention of the Summit, thematic content, illustrative image, or number of hyperlinks to other news.

\section{Results}

The analysis of the news broadcast during the 25th United Nations Conference reveals the presence of a high number of denialist news items related to the existence and relevance of the climate crisis, as well as a radical difference between media coverage.

This media polarization treatment confirms previous research findings $[5,17,20-23]$ about the preponderance of denialist positions in medias with a Republican orientation.

\subsection{News Issued by Media}

See Table 1 and Figure 3 for the frequency of news broadcasts. 
Table 1. Number of news items issued by each media during the 2019 United Nations Climate Summit.

\begin{tabular}{ccccc}
\hline Date & Breitbart & NYT & CNN & Fox News \\
\hline Dec 2 & 6 & 6 & 7 & 1 \\
Dec 3 & 5 & 4 & 5 & 3 \\
Dec 4 & 4 & 8 & 5 & 0 \\
Dec 5 & 3 & 14 & 4 & 2 \\
Dec 6 & 8 & 2 & 5 & 2 \\
Dec 7 & 5 & 3 & 0 & 0 \\
Dec 8 & 4 & 1 & 0 & 0 \\
Dec 9 & 6 & 3 & 2 & 1 \\
Dec 10 & 4 & 5 & 6 & 2 \\
Dec 11 & 8 & 4 & 4 & 2 \\
Dec 12 & 8 & 5 & 2 & 5 \\
Dec 13 & 5 & 58 & 42 & 22 \\
Total & 66 & & & 2 \\
\hline
\end{tabular}

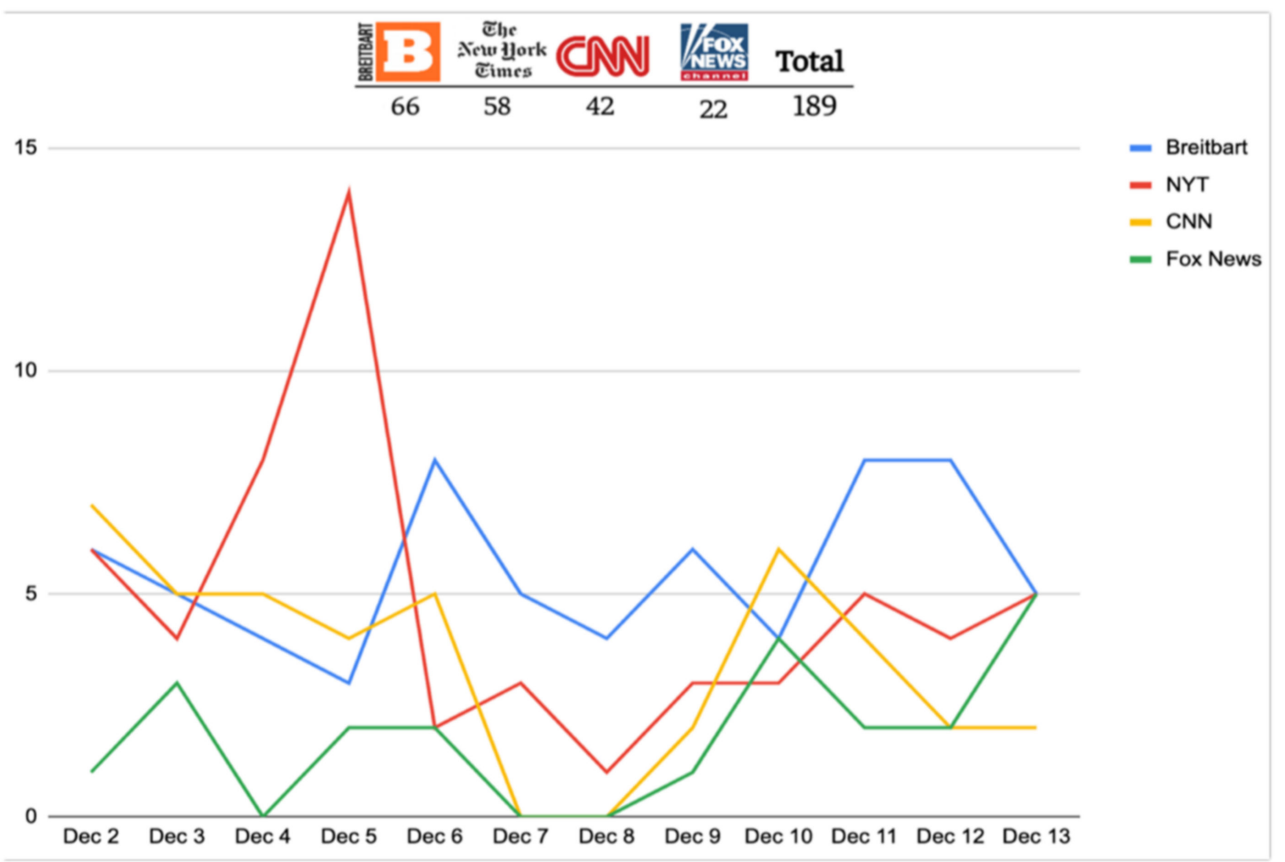

Figure 3. Amount of news issued by each media during the 2019 United Nations Climate Change Conference in Madrid.

A total of 189 news items were collected, from lowest to highest number of broadcasts: Fox News (22), CNN (42), the New York Times (58), and Breitbart (66), an overall average of 15 news items per day during the 12 days of the 2019 United Nations Climate Summit. Breitbart, a Republican political tendency media outlet, was in turn the one that broadcast the largest number of news items, while the other media outlet of the same political tendency, Fox News, broadcast the lowest number of climate news items of the entire sample. The Democratic political tendency media, the New York Times and CNN, occupied the second and third place after Breitbart in the quantity of news emitted. The relative average of news broadcast per day corresponds to Fox News (2), CNN (4), the New York Times (5), and Breitbart (6).

\subsection{Typology of News}

The pieces broadcast by the four media outlets were generally informative, fluctuating in a range of $71 \%$ to $83 \%$, and of $17 \%$ and $29 \%$ for opinion (see Figure $4 a$ ). The media with the highest percentage of opinion news was $\mathrm{CNN}$ at $29 \%$, even broadcasting two editorials dedicated to the reflection of current events related to climate change, followed by the New York Times at $24 \%$, with a weekly climate bulletin, and finally Fox News 
at $23 \%$, with opinions about how to depoliticize the climate change debate, and Breitbart at $17 \%$, with inquiries about the United Climate Summit and its relevance in global environmental policies.

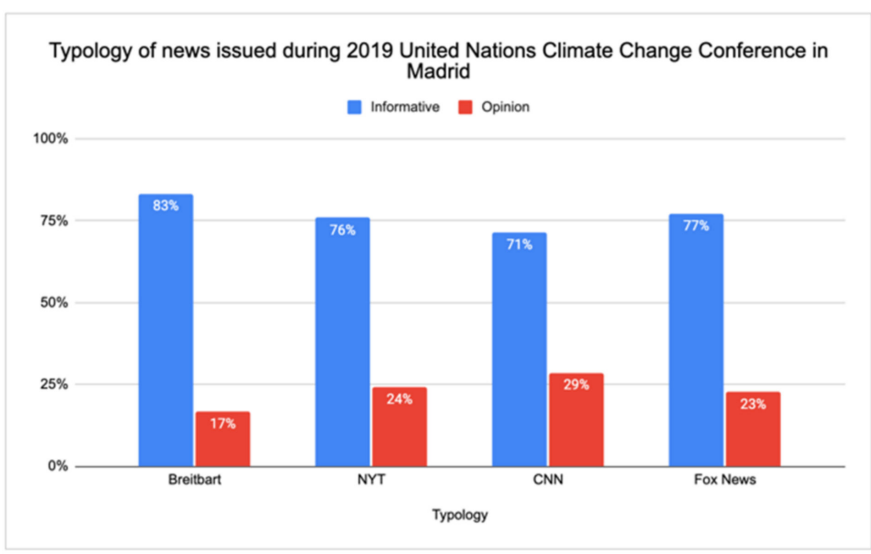

(a)

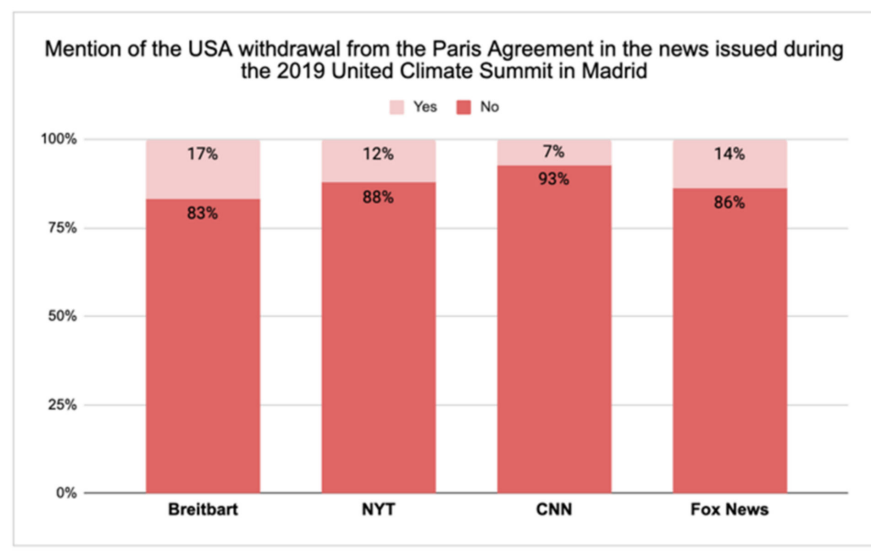

(b)

Figure 4. (a) Typology of news issued; (b) mention of the USA's withdrawal from the Paris Agreement in news.

In order to identify the level of depth and contextualization of the environmental problems in the country, the mention of the United States withdrawal from the Paris Agreement was registered. As shown in Figure $4 \mathrm{~b}$, this issue was rarely addressed in the news broadcast by the four media sources, although the media with a Republican political tendency reported the highest percentages of allusions compared to those with a Democratic political tendency.

\subsection{News Tagging}

The news tagging varied considerably by media. Breitbart used a large number of tags per news item, between five and 10, which included the general terms "climate change", "environment", and "climate" and more particular ones associated with specific events such as "Climate Summit COP 25" or "climate strikes", as well as labels with personality's names, such as politicians, celebrities, or activists. On the other hand, Fox News, CNN, and the New York Times handled unique labels, classifying the issue by sections that not all the time corresponded to "climate change". Fox News, for example, used labels that alluded to specific politicians and states where the news took place. CNN and the New York Times implemented similar labels, distributed by sections such as "Business", "Travel", and "Politics" or "Opinion: Turning Points" and "The Learning Network", respectively, incorporating the news into a more diverse sections within the information ecosystem, and not just as belonging to the "climate" section.

\subsection{Media Positions and Terminology Used}

Three possible positions were determined, applicable to both informative typologies and opinion in the news:

- Does not take position: The news is limited to narrate a fact or event. It provides information and contrasts sources. It does not make value judgments of any kind and focuses on the data.

- Denialist: The news presents information that discredits climate science, the institutions that promote preservation agreements, their activists, and/or politicians who issue statements to encourage environmental preservation.

- Activist: The news provides information that allows reflection around the negative consequences of climate change, and invites the readers to take an active position in the resolution of these consequences, either through the exaltation or the proposal of ecological initiatives. 
The results in Figure 5a show that only the Republican leaning media Breitbart and Fox News reported climate change denialist news. The Democratic leaning media, CNN and the New York Times, did not broadcast any such content. On the contrary, 38\% and $35 \%$ of their news, respectively, took an activist position on the climate emergency: "Climate change is accelerating, bringing the world perilously close to irreversible change", on December 4, is a New York Times headline that exemplifies this type of news. This particular piece exalts the consequences of climate change and links to reports by IPCC scientists warning of severe repercussions if $\mathrm{CO} 2$ and other greenhouse gas emissions are not reduced [45]. On CNN, news items such as "Call to Earth: How to travel without destroying the planet", on December 2, propose tips for "greening" vacations. The Swedish term flygskam, or "flight shaming", has motivated people to reduce, as much as possible, air transportation, prioritize lodging in small communities and not in large hotels to support the local economy, choose longer travel dates where travel is justified, and avoid crowds that deteriorate ecosystems, among others [46].

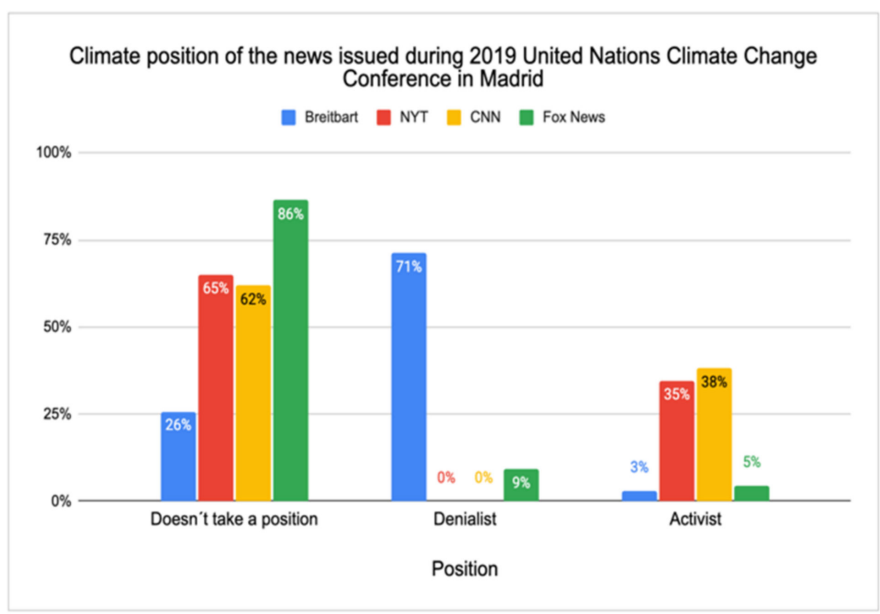

(a)

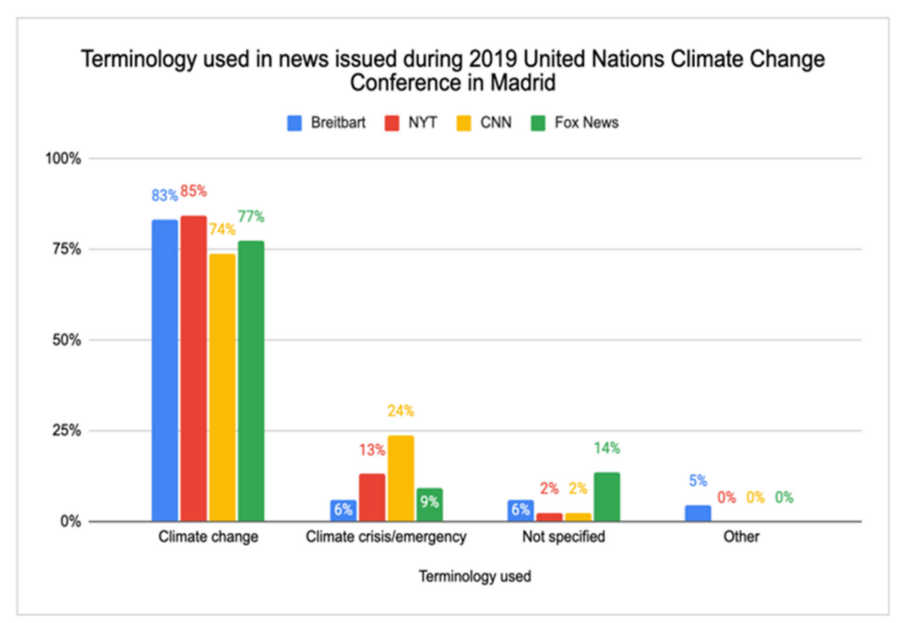

(b)

Figure 5. (a) Climate position of the news issued; (b) terminology used news issued.

Breitbart reflected a clear negationist position, with three quarters of its news being of this type $(71 \%)$, a quarter in which it did not take a position $(26 \%)$, and a minimum percentage of activist news (3\%). For its part, Fox News was notable for not taking a stand on the news (86\%) and for providing a lower percentage of denialist news $(9 \%)$ compared to the closest politically leaning media. Regarding the Democratic-leaning media, more than half of their news items did not take a stand $(62 \%$ of CCN and $65 \%$ of the New York Times), and the rest was activist news (38\% of CNN and $35 \%$ of the New York Times). CNN stands out as the media outlet that, in spite of not having the greatest Democratic political tendency, presented the greatest quota of activist news of the entire sample. Figure $5 b$ illustrates that between $74 \%$ and $85 \%$ of the total news items alluded to the term "climate change", while other terms such as "climate emergency" or "climate crisis" were much less used, in between $6 \%$ and $24 \%$ of news items. There was a correlation between the use of these last expressions and the percentage of activist news, due to the fact that the media that implemented them furthest were those that had more proactive positions in relation to the fight and awareness to stop climate change: CNN: $24 \%$, the New York Times: $13 \%$, Fox News: $9 \%$, and Breitbart: $6 \%$.

\subsection{Thematic Contents}

The news were classified in 11 thematic content categories that summarize in a general way the media's agenda setting during the COP 25 Climate Summit, identifying the issues more and less addressed by each one, as shown in Table 2: scientific studies about climate change (1), climate summit (2), climate strikes (3), climate scientists (4), environmental 
public policies (5), climate change consequences (6), statements by climate activists and politicians (7), political parties and climate change (8), ecological initiatives (9), fossil and energy industries (10), and Californian, Australian, and Amazonian forest fires (11).

Table 2. Number of news items issued by thematic content during the 2019 United Nations Climate Summit in Madrid.

\begin{tabular}{|c|c|c|c|c|}
\hline Thematic Content & Breitbart & NYT & CNN & Fox News \\
\hline Scientific studies about climate change & 2 & 5 & 8 & 1 \\
\hline Climate summit & 11 & 4 & 3 & 3 \\
\hline Climate strikes & 10 & 0 & 0 & 1 \\
\hline Climate scientists & 2 & 0 & 0 & 1 \\
\hline Environmental public policies & 4 & 3 & 0 & 1 \\
\hline Climate change consequences & 4 & 12 & 8 & 1 \\
\hline Statements by climate activists and politicians & 30 & 6 & 9 & 6 \\
\hline Political parties and climate change & 0 & 3 & 0 & 5 \\
\hline Ecological initiatives & 3 & 14 & 9 & 1 \\
\hline Fossil and energy industries & 0 & 8 & 1 & 0 \\
\hline California, Australian, and Amazonian forest fires & 0 & 3 & 4 & 2 \\
\hline Total & 66 & 58 & 42 & 22 \\
\hline
\end{tabular}

The thematic content approached was diverse in each media outlet; despite this, similar patterns were identified among media with Democratic and Republican political tendencies. For the New York Times and CNN, there were topics that were not reported at all, such as the climate protests in Washington DC on December 6, led by the climate NGOs Fonda Fire Drill and Shut Down DC [47], and news from climate scientists, such as the death of David Bellamy on December 12, a renowned British television presenter and naturalist climate change denier [48], both published by Breitbart. In contrast, the Republican political tendency media, Fox News and Breitbart, did not cover news related to the fossil and energy industry, like the victory of ExxonMobil in the lawsuit that the state of New York brought against it for the alleged fraud of representing the costs of regulating climate change to its investors [49], published by the New York Times on December 10.

Most Common Issues in Media with the Same Political Tendency

The New York Times and CNN agreed in the significant publication of ecological initiative news ( $24 \%$ and $21 \%$, respectively) as well climate change consequences news ( $21 \%$ and $19 \%$, respectively). The New York Times also reported questions about fossil and energy industries ( $14 \%$ of news items). CNN was the media outlet that broadcast the most scientific studies related to climate change news (19\%), followed by the New York Times $(9 \%)$. Breitbart and Fox News coincided in the emission of a greater quantity of news on declarations of climate activists and politicians ( $45 \%$ of Breitbart and $27 \%$ of Fox News), climate summit (17\% of Breitbart and 14\% of Fox News), and also climate strikes (15\% of Breitbart and $5 \%$ of Fox News). (See Figure 6). 


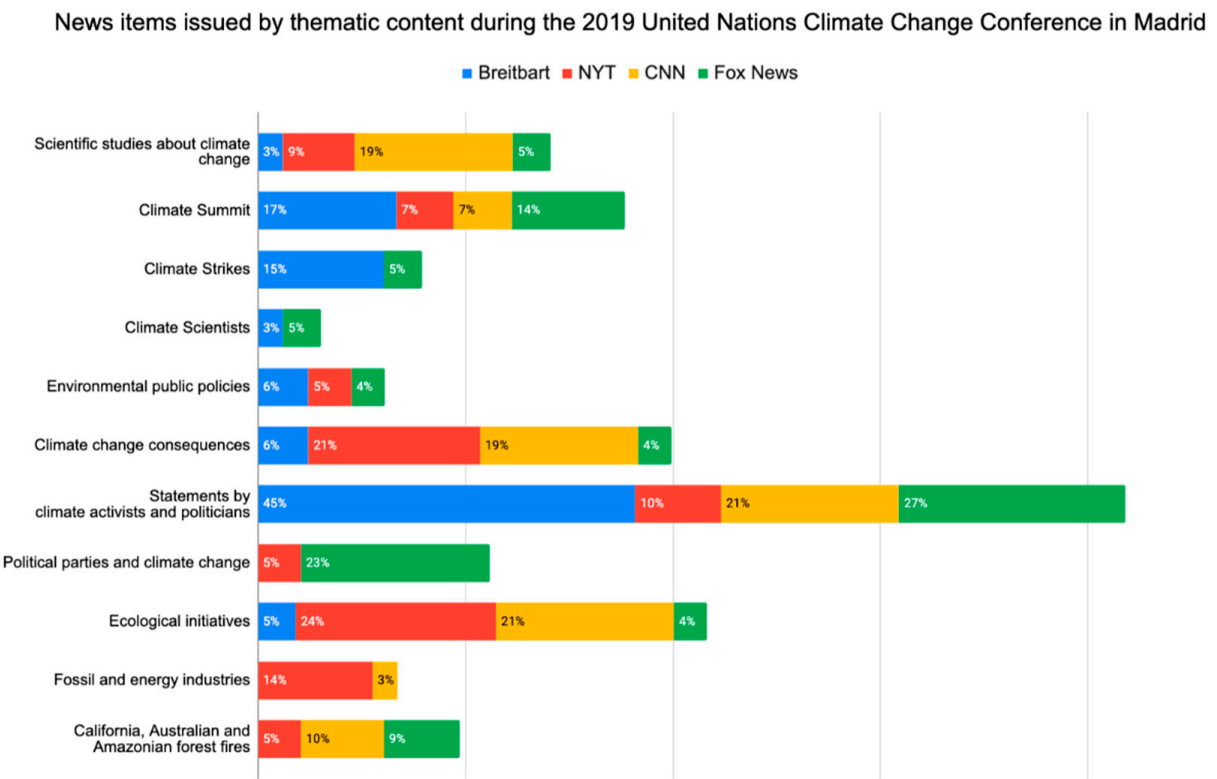

Figure 6. News items issued by thematic content. Note: relative percentages by media: the summary must be equal to $100 \%$ for each media associated with a color, not for each thematic content.

\section{Discussion}

This research has made it possible to analyze the construction of public opinion on climate change in the United States [5] from a comparative approach to the information and opinion coverage that the Republican and Democratic political orientation media [16] gave to the climate crisis during the 12 days of the 2019 United Nations Climate Summit in Madrid. The results reveal that the media with Republican political tendencies, Breitbart and Fox News, were the only ones that expressed denialist positions on climate change. The first of these, with the greatest political inclination, was in turn the one that broadcast the greatest quantity of news during the summit, supporting the postulates of authors who link the influence of fossil fuel and coal industry lobbies on US Republican policy $[7,18,21-23,26,28-30]$ with the intention of undermining scientific consensus, fragmenting public opinion, and delaying environmental legislation.

The news coverage, from the thematic perspective, shows clearly antagonistic positions between the media, $\mathrm{CNN}$, and the New York Times for ecological initiatives, consequences of climate change such as extreme weather events, studies related to climate science, and news about the fossil industry. For example, the New York Times mentioned the fossil and energy industry as well as comments from denialist sources on average two times more than Breitbart, which did not broadcast news on this topic.

In this regard, studies about the presence of the climate change countermovement (CCM) in major print and television news segments reveal that in years such as 2017, more than half of the coverage provided to these organizations comes from left-leaning politically oriented media outlets like the Washington Post and the New York Times [50]. They conclude that singling out and shaming the right-wing media for amplifying the volume of CCM organizations and their associated contrarians is misplaced. Additionally, the strategy of criticizing such skeptical positions generates the opposite effect, because minority and non-consensual discourse takes place in the debate. Meanwhile, Breitbart and Fox News shows climate strikes, statements of politicians and climate activists, the climate summit, and political parties. The 2019 United Nations Climate Summit was not a point of reference for discussion of climate change in the Democratic-oriented media as it was for the Republican-oriented media, which made major mention both of the event and the United States' withdrawal from the Paris Agreement (see Figure 4b). In this regard, CNN and the New York Times proposed a discourse on climate change that omitted the U.S. exit from the Paris Agreement, as well as the summit, and focused on the initiatives that states 
and cities are implementing to reduce their emissions. Fox News and Breitbart continued to put forward an environmentalist discourse focused on arguing for Donald Trump's decision to withdraw from the Paris Agreement from advocacy to economic issues and denial of climate responsibilities. Previous research [32] has postulated that personalization, dramatizations, and the order of balance and authority, also called journalistic standards, which determine the selection and content of the news, hinder a correct treatment of the information.

The results reveal that the deliberate omission makes it difficult for the public to construct a broad framework, considering that both the international event and the exit of the United States from the agreement are key elements to understand the environmental crisis in a global and national context, and also because it detracts from the climate skepticism professed by the current government.

The non-inclusion of certain themes in media with a contrary political tendency (for Republicans, the fossil and energy industry, and for Democrats, climate protests and news about climate scientists) reveals that the informative selection of the data each media outlet does or does not publish corresponds to the particular interests it promotes, enhancing those that reinforce its arguments and omitting those that may contradict them. However, this strategy generates an informative bias, which relativizes the perception of reality through highly biased discourses, which make visible and invisibilize, deliberately, events and information, in order to serve its neighbors, in a kind of echo chambers [36,37]. According to the Spanish media statement [51], climate change coverage should promote the frequency and continuity of quality information on climate change; influence not only the impacts of climate change, but also causes and solutions; promote a focus of the problem from the point of view of climate justice; connect the phenomenon of climate change with close realities in space and time to demonstrate that climate change is not future but present; disseminate initiatives undertaken or led by citizens; defend critical and independent journalism; disseminate scientific research around climate change; popularize the specific terminology necessary for understanding the phenomenon; connect climate change with extreme weather phenomena; and increase specialized writings.

\subsection{News Personalization and Dramatization}

The surveyed media gave significant coverage to the statements of activists and politicians (Breitbart 45\%, CNN 21\%, Fox News 27\%, and to a lesser extent, the New York Times, giving 10\%). In addition, there was a correlation between a higher percentage of denialist news in the Republican-leaning media, Breitbart and Fox News, and personalized and dramatic coverage of news events. These results are in line with the theory about journalistic rules that affect the selection and approach to news [32], especially from the perspective of personalization: the most attractive news tends to be of individuals and personalities, rather than group dynamics or social processes, and dramatization: news dramas emphasize the crisis of continuity and minimize complex information about policies and the power bases behind the central characters. This approach also generates an informational bias in the coverage of climate change, as attention is focused on statements by politicians or climate activists, which, beyond their political stance, make it difficult to present a broader picture that contextualizes causes, consequences, and mitigation actions. Several Breitbart news items addressed the COP 25 Climate Summit, but from a case-by-case approach, through politicians and activists who framed the news, making it apparently more attractive to the reader:

"Spanish leader scolds climate change deniers and urges 'fanatics' to repent", December 2 [52]; "Nancy Pelosi assures the UN: 'We're still in' to fight global warming", December 2, alluding to the permanence of the United States in the Paris Agreement [53]; "Thunberg takes her climate protest to the host of the UN Climate Summit Madrid", December 6 [54].

Based on the discursive study of the pieces and the current events that took place in the period under examination, it is possible to attribute this personalization and dramatization of the news to two factors: firstly, the pre-electoral context in the country during that period, 
the Democratic Party candidacy for the November 2020 presidential elections, illustrated, for example, by headlines such as this one on December 10, on Fox News: "Elizabeth Warren announces Blue New Deal for our oceans" [55] about the former Democratic candidate and her proposal for an agreement for the preservation of the oceans, in analogy to the Green New Deal suggested by New York representative Alexandria Ocasio-Cortez to confront climate change and the financial crisis. Secondly, the controversial relationship between the young climate activist Greta Thunberg and politicians such as the President of Brazil, Jair Bolsonaro, and the President of the United States, Donald Trump, has aroused increasing interest among the public opinion and has been fueled by the exchange of confrontational tweets between the parties involved. Fox News and Breitbart gave extensive coverage to these messages. Headlines like these reflect it: "Greta Thunberg called 'brat' by Brazilian president", December 11 on Fox News [56]; "Michelle Obama defends Greta Thunberg after Trump mocks: 'Ignore the doubters'", December 13 on Breitbart [57].

\subsection{Climate Change Denial Strategies in Media with Republican Political Tendency}

\subsubsection{Fox News: Thematic Disinterest in Coverage}

Although this media outlet did not have a considerable amount of news with a denialist position (only $9 \%$, in comparison with $71 \%$ of Breitbart), this little amount of climatic news broadcast, as well as the lack of position of the same, shows a thematic disinterest. In Borrat's words, the newspaper is a political actor, which has the capacity to affect the decision-making process in the political system. Its scope of action is from the influence to interest groups, political parties, social movements, governments, and public opinion in general. It receives multiple pieces of information from polyphonic sources, which it decides to include, exclude, and/or prioritize [58] In this respect, the exclusion or omission of information on climate change by Fox News, which broadcast an average three times less news than the other media, reflect a denialism that is not as evident as in Breitbart, but which also diminishes the importance of this problem and consequently contributes to its invisibility in the public debate. The skeptical news in this media outlet employed the tactics of neutralization of climate change denial of responsibility, condemning the condemner, and appeal for greater loyalty [28], to support their arguments. Here are some examples: "Gutfeld: on 'existential' and 'climate emergency' as words of the year", December 3:

Oxford Dictionaries chose "climate emergency" as their word of the year, even though there are two of them. Oxford said that its use reflects the "spirit, mood, or concerns of the passing year". Translation: it is what rich, elite liberal parrots repeat when they board planes for a vacation in France. I remember when dictionaries were great. They contained words, not the politics of pretentious editors. Now they are like any other medium, full of eager social climbers fighting for relevance [59].

In this article, the tactic of condemning the condemner is evident [28] when he refers disparagingly to politicians who promote environmental initiatives, delegitimizing the use and recognition of the word "climate emergency". "Jim Breslo: California Democrats are pursuing the wrong policies to reduce fires. They should be doing THIS", December 6:

California has a fire problem, but has not been able to manage it, because they consider fires to be a consequence of climate change and these are due to the atmospheric and geographic conditions of California [...] California does not achieve change with such policies because China and India are increasingly polluting, pollution that spreads through the Pacific to the United States and Californians continue to gobble up Chinese products. To reduce forest fires, California must immediately improve its electrical infrastructure, clear brush, eliminate homeless camps (the cause of 2500 fires in Los Angeles alone last year), add firefighters, and improve the state's antiquated response system, but it is not doing so because wildfires promote a progressive green energy agenda [60].

In Breslo, the denial of responsibility tactic [28] is perceived as ignoring the association between climate change and forest fires; although it is not the only cause, science warns 
of the relationship between higher temperatures and the spread of fires, as detailed in the latest IPCC report, which states that "the impacts associated with other biodiversity risks, forest fires, and the spread of invasive species are less with a global warming of $1.5^{\circ} \mathrm{C}$ than with one of $2{ }^{\circ} \mathrm{C}^{\prime \prime}[1]$ (p. 10). Based on what was observed in this study, it is suggested to add to McKie's denial tactics [28] the tactic of the common enemy, which is based on the transfer of responsibilities to a subject, institution, or country that embodies the opposite ideals, and therefore is a motive for attack. In the Breslo news item [60], these common enemies are China and India, which are identified as major polluters, and China is presented as an enemy economic monopoly that has penetrated the U.S. market, threatening the nation. This dichotomy between "the good side and the bad side" promotes the denial of the country's responsibility for climate action [28].

\subsubsection{Breitbart}

The negations of climate change in Breitbart were the highest among the four media studied, with a percentage of negative news of $71 \%$, making clear its position on this topic. The forms of climate change denialism or skepticism are characterized in its discourse:

\section{Spectacularization of Climate Change and ad Hominem Attacks}

Very often, news in this media outlet gave coverage to statements of inexperienced people on climate change, or to strikes led by Hollywood celebrities, leaving aside scientific studies on climate, or public policies that are being developed in the country that could provide valuable information for the understanding of the environmental emergency. Breitbart's speech aims to link the climate initiative, almost uniquely, with the actors, actresses, and singers of the entertainment world, presenting them as the standard-bearers of the cause, with the intention of spectacularizing the ecological initiative and delegitimizing their convictions, as if it were a kind of "show" of the Hollywood world. The enormous amount of news of this type, $45 \%$ of those broadcasts by the media, catalogued as news and/or declarations by activists, politicians, and celebrities (see Figure 6, is evidence of this intention.

Some headlines are highlighted: "Julia Louis-Dreyfus raises funds for the anti-Trump environmental lobby, fighting to 'ensure a planet for the next generation'", December 3 [61] and December 6 [62]; "Young Sheldon star Iain Armitage upset because he was too young to be arrested at Jane Fonda's climate protest", December 9 [63]; "Steve Harvey rolls his eyes after reading the question about climate change in the Miss Universe contest". These pieces do not provide information that allows us to understand the debate on climate change, the scientific evidence that justifies its importance, the public policies with which governments are confronting it, or the resilient initiatives in the territories. Instead, they limit themselves to pointing out irrelevant information about the opinions and actions of people in the entertainment world, who, although they are linked, represent only a minority part of the struggle to halt climate change.

In addition, ad hominem attacks on climate activists and politicians sympathetic to environmental initiatives were constantly in the news. Arguments were used that attacked people with different political tendencies, with the aim of distorting their proposals. Some pieces of this type are outlined below: "The self-proclaimed 'global leader' of climate change Mike Bloomberg enjoys his own fleet of private planes and helicopters", December 9.

Billionaire Michael Bloomberg, with an estimated value of $\$ 54$ billion, enjoys his own fleet of private planes and helicopters stationed in New Jersey while describing himself as a "world leader" in the environment and climate change. Inside sources described in January how Bloomberg's private jet probably "generates about 37 times more carbon emissions than the same trip on a commercial flight" [64].

"From Hitler and Stalin to Greta Thunberg: TIME Loves to Celebrate Totalitarian Icons", December 11: 
Adolf Hitler 1938. Joseph Stalin 1939. Joseph Stalin (again) 1942. Ayatollah Khomeini 1979. Greta Thunberg 2019. TIME magazine has not lost its infallible ability to put its finger on the pulse of the spirit of the times, invariably succeeding in naming a Person of the Year that perfectly sums up the madness. [...] Today it is "Environmentalism". Remember, Greta Thunberg is a teenage dropout. It is not because of her scientific background that she has been selected as the current figure in the global environmental movement, but because of her youth. Part of her role is to represent the "future generations" that the green narrative tells us are most threatened by climate change [...] The catastrophic man-made global warming is a hoax. It only exists in unreliable computer models and the overactive imagination of a frightened 16-year-old schoolgirl [65].

Swedish activist Greta Thunberg has embodied a "pseudo leadership" of global climate activism, which in turn has made her a victim of various attacks, such as those already commented on by the presidents of Brazil and the United States. Breitbart has been especially active in covering and even promoting these attacks, as this opinion piece shows, so that the attention that should be given to green climate change mitigation initiatives, which encourage collective action, is translated into these types of statements and polemics about activists and politicians, which disinform and polemicize public opinion.

\section{Ecofascism and the Radical Left}

Various news items in this media postulate a supposed relationship between environmentalism and radical leftist communist policies, linking regulations of the fossil industry and other ecological proposals with strategies planned by the leftists to transform the United States into a communist regime. This argument is also present in previous studies $[24,25]$. News like this reflects these postulates:

"Delingpole: ecological policies are turning Chile into Venezuela", December 4.

Most importantly, in fact the only thing you need to know about the last UN climate circus, COP 25, is that it was originally going to be held in Santiago, Chile. But the ecological policies introduced by the country's president, Sebastián Piñera, have proved so disastrous and unpopular that Chile is on fire. It began with protests over ticket prices in the Chilean subway, which rose by $200 \%$. The increase was the result of Piñera's push for renewable energy, who wants the country to become carbon neutral by 2035 [...] It is true that the revolution has been hijacked by the extreme left, just as in France with the yellow vest protests, which originally began as a protest against the increases in fuel prices, again the result of an ecological policy. Good, greenies. They have no right to high morals. What they are doing to the planet is pure evil [66].

"Britain's political class has surrendered to the green stain", December 9.

[...] The main goal of environmentalism is to promote leftist causes: redistribution of wealth, larger government, identity politics, the destruction of Western industrial civilization, the promotion of "experts" and commissioner-style technocrats, state-imposed restrictions on freedom, behind a layer of green justice. Watermelons: green on the outside, red on the inside [...] There is no credible evidence that the world is facing a "climate crisis", let alone that it is "the biggest problem the UK faces as a nation". What? Not Brexit? Immigration? Health care? Violent crime? The economy? Yet all the major parties, even the Conservatives, have accepted the false narrative written by the kind of people who hate them and always will [67].

These types of arguments are almost always accompanied by comments of class division. They claim that environmentalists are in turn the "evil" elite, who promote unworkable ideals that even they themselves cannot fulfill, while the lower class, which is the least polluting, must sacrifice its few comforts to adapt to green policies that completely ignore their interests.

\section{Half-Truth Fallacy and Questionable Sources}

As part of the argumentative strategies to deny climate change, the news in Breitbart mentions scientific studies that supposedly distort the veracity of climate science. The 
cited studies are presented as fragments with isolated phrases, which apparently adapt to the news' denialist narrative, but if they are carefully reviewed in the original study, they contradict each other. This is the case in the news item on December 2: "UN blames climate change for massive global migration".

Climate change and displacement: How are they connected? The UN Office of Migration (UNHCR) states in a video that rising sea levels, drought, floods, forest fires, and other natural hazards are forcing people to flee their homes, and provides the testimony of a woman affected by the rains in Zimbabwe. However, studies show that rainfall in Zimbabwe has decreased in recent years (study 1), and the percentage of deaths from extreme weather events has decreased by $97.8 \%$ compared to the 1990s (study 2), so humanity is managing extreme weather events extraordinarily well, regardless of whether they are increasing [68].

Delving deeper into the studies cited, in the first "Climate problems and facts, from the Zimbabwean Meteorological Department", there is no such affirmation as that "rainfall in Zimbabwe has decreased in recent years", as presented in the news. On the contrary, the quote from the original study indicates that rainfall decreases in some months and increases in others: "Increased rainfall in the months of October and December, November, January, February, and March reveal a downward trend" and "observed trends reveal different patterns emphasizing the occurrence of floods and droughts in the country" [69] (p. 38). This same study even devotes special sections where it confirms that the region has experienced changes in the climate system. It mentions, for example, that "the average annual maximum and minimum air temperature has increased by about 2 degrees Celsius, respectively, over the last 100 years" [69] (p. 31). The second study, "Wealth and Security: The Astonishing Decline in Extreme Weather Deaths in an Era of Global Warming, 19002010" [70], comes from the Reason Foundation, a well-known non-profit organization engaged in promoting the values of freedom, individual choice, limited government, and market-friendly policies, which is funded by the David H. Koch Charitable Foundation, owned by the Koch Industries petrochemical company [71], whose repeated interest in promoting climate change denial has been pointed out by several authors [20-22].

The news distorts the truth, through studies of dubious origin, or with half-assertions, which lose validity in their original discourse. As Mckie affirms, [28] denial tactics are no longer focused exclusively on denying the existence of climate change; instead, they are based on attacks on the emitter of the message, activists, and politicians in favor of environmental causes, as well as the lack of knowledge about the relationship between extreme climate events and changes in the climate system.

\section{Conclusions}

The diversity of content broadcast by the media nourishes the information ecosystem and contributes to a broader understanding of reality [58]. The U.S media have expressed their position through editorial articles in which they take sides on the climate change situation. However, this position is also manifested in the process of selecting commentators in opinion columns, the process of selecting information, the hierarchy of information, and the fact of giving a voice to some protagonists over others. The radical difference in the climate news coverage between the Democratic and Republican politically oriented media reveals an information bias generated by the polarization and politicization of the climate phenomenon and confirms the results of previous research $[5,17,20-23]$ on the preponderance of denialist positions in the Republican-oriented media.

The media are political actors that participate in this process of public discussion, issuing speeches to combat or deny the climate emergency. Despite this, it is important to recognize their limitations as corporate-owned organizations that could also be affected by the implementation of regulations that prioritize environmental well-being and the sustainability of ecosystems and resources over the economic profitability of capital. The polarization, when it becomes too extreme, is especially dangerous for the liberal democratic 
order, because it gives rise to social and political conflict, making political compromise, let alone consensus, almost impossible. [72].

Joe Biden's victory in the 2020 presidential election [73] represents a more hopeful horizon for national and international climate action. Some of his proposals include the transition from fossil fuels to renewable energy, mandatory disclosure of climate risks by public companies, the intention to end new drilling permits for federal lands, and the elimination of tax subsidies for the oil and gas industry [74]. Indeed the reintegration of the United States into the Paris Climate Agreement on 21 January 2021, was one of his first actions as president. [75]. This new phase will certainly bring radical changes to the national political, social, economic, and environmental agenda. In spite of this, American society faces the challenge of combating polarization and extremist speeches that have been increasing in recent days, as was evidenced on January 8 when a group of attendees of a presidential rally convoked by Donald Trump violently went to the Capitol with the intention of interrupting the certification of congressional votes that would give Joe Biden the victory in the elections [76], leaving five people dead and several more injured [77].

A decisive and synergic climate action, which allows reaching the objectives proposed in the Paris Agreement, requires a depoliticization of climate change, which promotes awareness and a need to mitigate the climate emergency. The country's media have a very important role to play in this process; the selection and dissemination of the information broadcast, the thematic frames and the sources used, the diffusion of science, the exaltation of the environmentally responsible initiatives that are being carried out in the territories, the exposure of the causes and consequences of climate change, the preponderance of an approach to the problem from the point of view of climate justice, the specialized editorial staffs, and the connection between extreme weather events and climate change are key in this process [51].

There is a clear relationship between the role of the media analyzed and their position on climate change, whereby the media adopt their own narratives and give voice to the most relevant actors who refute their ideological position [12,40]. These positions are shown in the use of terminology, as in the case of the term climate change (denialists), as opposed to climate emergency (activists), which corresponds to the frames configured in each media outlet. Likewise, there is a presence of personalization in the arguments and actors, with a dramatization of positions and consequences, as has been reflected in other research on the presence of dramatic elements in the discursive strategies of the actors involved in the process [13,32].

In future studies, it would be of particular interest to delve into the discourses on climate action of the more liberal and conservative wings of the Democratic and Republican parties in U.S, and also to investigate the media framing of the climate emergency in leading climate action countries such as those of Eastern Europe to broaden the comparative and reference framework of media coverage that increases a climate action.

Author Contributions: Conceptualization: S.L.G. and A.C.E.; methodology: A.C.E.; validation: S.L.G., formal analysis: S.L.G. and A.C.E.; investigation: S.L.G.; resources: A.C.E.; data curation: S.L.G.; writing—original draft preparation: S.L.G.; writing—review and editing: S.L.G. and A.C.E.; visualization: S.L.G.; supervision: A.C.E. All authors have read and agreed to the published version of the manuscript.

Funding: This research received funding from the University of Malaga, Spain.

Institutional Review Board Statement: Not applicable.

Informed Consent Statement: Not applicable.

Data Availability Statement: Not applicable.

Conflicts of Interest: The authors declare no conflict of interest. 


\section{References}

1. IPCC. IPCC Special Report on the Impacts of Global Warming of $1.5^{\circ}$ C. 2019. Available online: https://www.ipcc.ch/sr15/ (accessed on 10 May 2020).

2. UNFCCC. What Is the Paris Agreement? UNFCCC: Rio de Janeiro, Brazil; New York, NY, USA, 2016.

3. Mars, A. Trump Notifica su Portazo al Acuerdo de París Contra el Cambio Climático. 2019. Available online: https:/ / elpais.com/ sociedad/2019/11/04/actualidad/1572901274_683382.html (accessed on 30 November 2020).

4. UNFCCC. Emissions Gap Report; UNFCCC: Rio de Janeiro, Brazil; New York, NY, USA, 2018.

5. Krosnick, J. American Public Opinion on Global Warming; Stanford's Political Psychology Research Group (PPRG): Stanford, CA, USA, 2018.

6. Moser, S.C. Reflections on climate change communication research and practice in the second decade of the 21st century: What more is there to say? Wires Clim. Chang. 2016, 7, 345-369. [CrossRef]

7. Nerlich, B.; Koteyko, N.; Brown, B. Theory and language of climate change communication. Wires Clim. Chang. 2010, 1, 97-110. [CrossRef]

8. Schäfer, M.S. Online communication on climate change and climate politics: A literature review. Wires Clim. Chang. 2012, 3, 527-543. [CrossRef]

9. Bell, A. Media (mis)communication on the science of climate change. Public Underst. Sci. 1994, 3, 259-275. [CrossRef]

10. Chapman, D.A.; Lickel, B.; Markowitz, E.M. Reassessing emotion in climate change communication. Nat. Clim. Chang. 2017, 7, 850-852. [CrossRef]

11. Bolsen, T.; Shapiro, M.A. The US News Media, Polarization on Climate Change, and Pathways to Effective Communication. Environ. Commun. 2018, 12, 149-163. [CrossRef]

12. Carvalho, A.; van Wessel, M.; Maeseele, P. Communication Practices and Political Engagement with Climate Change: A Research Agenda. Environ. Commun. 2016, 11, 122-135. [CrossRef]

13. Bevan, L.D.; Colley, T.; Workman, M. Climate change strategic narratives in the United Kingdom: Emergency, Extinction, Effectiveness. Energy Res. Soc. Sci. 2020, 69, 101580. [CrossRef]

14. Entradas, M. What is the public's role in 'space' policymaking? Images of the public by practitioners of 'space' communication in the United Kingdom. Public Underst. Sci. 2016, 25, 603-611. [CrossRef]

15. Entradas, M.; Bauer, M.M. Mobilisation for public engagement: Benchmarking the practices of research institutes. Public Underst. Sci. 2017, 26, 771-788. [CrossRef]

16. Newman, N.; Fletcher, R.; Kalogeropoulos, A.; Nielsen, R.K. Reuters Institute, Digital News Report 2019; University of Oxford: Oxford, UK, 2019.

17. Beder, S. Lobbying, greenwash and deliberate confusion: How vested interests undermine climate change. In Green Trends and Environmental Politics; Asia-Seok Digital Technology: Taipei, Taiwan, 2014; pp. 297-328.

18. Bonds, E. The knowledge-shaping process: Elite mobilization and environmental policy. Crit. Sociol. 2011, 37, 429-446. [CrossRef]

19. Global Warming Policy Foundation. 900+ Peer-Reviewed Papers Supporting Skepticism of "Man-Made" Global Warming Alarm; Global Warming Policy Foundation: London, UK, 2011.

20. Greenpeace. Koch Industries: Secretly Funding the Climate Denial Machine; Greenpeace: Washington, DC, USA, 2010.

21. Greenpeace. Greenpeace Briefing. Donors Trust: The Shadow Operation That Has Laundered \$146 Million in Climate-Denial Funding; Greenpeace: Washington, DC, USA, 2013.

22. Mayer, J. Dark Money: The Hidden History of Billionaires behind the Rise of the Radical Right in the United States; Anchor: Mexico City, Mexico, 2016.

23. McCright, A.M.; Dunlap, R.E. Cool dudes: The denial of climate change among conservative white males in the United States. Glob. Environ. Chang. 2011, 21, 1163-1172. [CrossRef]

24. Oreskes, N.; Conway, E.M. Merchants of Doubt. How a Handful of Scientists Obscured the Truth on Issues from Tobacco Smoke to Global Warming; Bloomsbury: London, UK, 2010. [CrossRef]

25. Michaels, D. Doubt Is Their Product. How Industry Assault on Science Threatens Your Health; Oxford University Press: New York, NY, USA, 2008.

26. Dunlap, R.E.; Jacques, P.J. Climate Change Denial Books and Conservative Think Tanks: Exploring the Connection. Am. Behav. Sci. 2013, 57, 699-731. [CrossRef] [PubMed]

27. Cann, H.W. Climate Change, Still Challenged: Conservative Think Tanks and Skeptic Frames. In Proceedings of the Annual Meeting of the Western Political Science Association, Las Vegas, NV, USA, 2-4 April 2015.

28. Mckie, R.E. Climate Change Counter Movement Neutralization Techniques: A Typology to Examine the Climate Change Counter Movement. Sociol. Inq. 2018, 89, 288-316. [CrossRef]

29. Boykoff, M.T. Consensus and contrarianism on climate change. How the USA case informs dynamics elsewhere. Mètode Sci. Stud. J. 2016, 6, 89-95. [CrossRef]

30. Kennedy, D. How Fox News Is Helping to Destroy the Planet. 2019. Available online: https://www.wgbh.org/news/ commentary /2019/12/03/how-fox-news-is-helping-to-destroy-the-planet (accessed on 30 November 2020).

31. Doyle, J. Picturing the climactic: Greenpeace and the representational politics of climate change communication. Sci. Cult. 2007, 16, 129-150. [CrossRef] 
32. Boykoff, M.T.; Boykoff, J.M. Climate change and journalistic standards: A case study of US media coverage. Geoforum 2007, 38, 1190-1204. [CrossRef]

33. Díaz Nosty, B. The Symbolic Rupture of Scientific Consensus: An interdisciplinary Approach to Climate Change; The Case of the United States; Fundación Dialnet: La Rioja, Spain, 2015; pp. 185-201.

34. Weart, S. Global warming: How skepticism became denial. Bull. At. Sci. 2011, 67, 41-50. [CrossRef]

35. Norgaard, K.M. Climate Denial: Emotion, Psychology, Culture, and Political Economy. In The Oxford Handbook of Climate Change and Society; Dryzek, J.S., Norgaard, R.B., Schlosberg, D., Eds.; Oxford University Press: Oxford, UK, 2011; pp. 144-160.

36. Walter, S.; Brüggemann, M.; Engesser, S. Eco-Denial Chambers: Explaining User Comments on Climate Change. Environ. Commun. 2018, 12, 204-217. [CrossRef]

37. Samantray, A.; Pin, P. Credibility of climate change denial in social media. Palgrave Commun. 2019. [CrossRef]

38. Castillo-Esparcia, A.; Almansa-Martínez, A.; Smolak-Lozano, E. East European think tanks in social media-Towards the model of evaluation of effective communication/PR strategies: Case study analysis. Catalan J. Commun. Cult. Stud. 2015, 7, 231-250. [CrossRef]

39. Bolsen, T.; Palm, R.; Kingsland, J.T. The Impact of Message Source on the Effectiveness of Communications about Climate Change. Sci. Commun. 2019, 41, 464-487. [CrossRef]

40. Castillo-Esparcia, A.; Castillero-Ostio, E. Investigación en comunicación: Metodologías, temáticas y fuentes. Rev. Int. Relac. Públicas 2019, 9, 197-218. [CrossRef]

41. Castillo Esparcía, A.; Almansa Martínez, A. Estudio sobre la estructura y el funcionamiento de los gabinetes de comunicación en España. Anagramas Rumbos Sentidos Comun. 2004, 2, 47-62.

42. Levine, A.S.; Kline, R. A new approach for evaluating climate change communication. Clim. Chang. 2017, 142, 301-309. [CrossRef]

43. Mas-Manchón, L.; Guerrero-Solé, F. The use of hashtags as a political branding strategy. Rev. Int. Relac. Públicas 2019, 9, 5-24. [CrossRef]

44. Maeseele, P.; Pepermans, Y. Ideology in Climate Change Communication; Oxford Research Encyclopedia of Climate Science: Oxford, UK, 2017.

45. Fountain, H. Climate Change is Accelerating, Bringing the World Dangerously Close to Irreversible Change; New York Times: New York, NY, USA, 2019.

46. Buckley, J. How to Travel without Destroying the Planet. 2019. Available online: https://edition.cnn.com/travel/article/greentravel-tips/index.html (accessed on 23 March 2021).

47. Kent, S. Watch Live: Leftists March to Shut Down D.C. Banks. 2019. Available online: https://www.breitbart.com/politics/2019 /12/06/watch-live-leftists-march-to-shut-down-d-c-banks / (accessed on 30 November 2020).

48. Delingpole, J. Delingpole: RIP David Bellamy-Nature TV Star Cancelled by BBC for Climate Change Wrongthink. 2019. Available online: https:/ / www.breitbart.com/europe/2019/12/12/rip-david-bellamy-cancelled-by-the-bbc-for-green-wrongthink/ (accessed on 30 November 2020).

49. Schwartz, J. New York Loses Climate Change Fraud Case Against Exxon Mobil; New York Times: New York, NY, USA, 2019.

50. Boykoff, M.T.; Farrell, J. Climate change countermovement organizations and media attention in the United States. In Climate Change Denial and Public Relations: Strategic Communication and Interest Groups in Climate Inaction; Almiron, N., Xifra, J., Eds.; Routledge: New York, NY, USA, 2020; pp. 121-139.

51. ECODES \& MDCS. Declaración de los Medios de Comunicación Frente al Cambio Climático. 2019. Available online: https: / / ecodes.org/docs/Medios_Comunicacion_Cambio_Climatico.pdf (accessed on 1 December 2020).

52. Kent, S. Spanish Leader Scolds Climate Change Deniers, Urges 'Fanatics' to Repent. 2019. Available online: https://www. breitbart.com/environment/2019/12/02/spanish-leader-scolds-climate-change-deniers-urges-fanatics-to-repent/ (accessed on 30 November 2020).

53. Caplan, J. Nancy Pelosi Assures U.N: 'We're still in' to Fight Global Warming. 2019. Available online: https:/ /www.breitbart. com/politics/2019/12/02/pelosi-assures-un-conference-that-us-committed-to-fight-climate-change/ (accessed on 30 November 2020).

54. AFP. Thunberg Brings Her Climate Protest to UN Climate Summit Host Madrid. 2019. Available online: https: / / www.business-standard.com/article/pti-stories/thunberg-brings-her-climate-protest-to-un-climate-summit-host-madrid119120700023_1.html (accessed on 30 November 2020).

55. Dorman, S. Elizabeth Warren Announces ‘Blue New Deal for Our Oceans'. 2019. Available online: https://www.foxnews.com/ politics/elizabeth-warren-blue-new-deal (accessed on 30 November 2020).

56. Stimson. Greta Thunberg Called a 'brat' by Brazilian President. 2019. Available online: https://news.sky.com/story/gretathunberg-called-a-brat-by-brazils-president-jair-bolsonaro-11883240 (accessed on 30 November 2020).

57. Caplan, J. Michelle Obama Defends Greta Thunberg after Trump Mocks: 'Ignore the Doubters'. 2019. Available online: https:// www.breitbart.com/politics/2019/12/13/michelle-obama-defends-greta-thunberg-after-trump-mocks-ignore-the-doubters / (accessed on 10 May 2020).

58. Borrat, H. El periódico, actor del sistema politico. Análisis 1989, 12, 67-80.

59. Gutfeld, G. Gutfeld on 'Existential' Being Word of the Year. 2019. Available online: https://www.foxnews.com/opinion/gutfeldexistential-word-year (accessed on 30 November 2020). 
60. Breslo, J. Jim Breslo: California Democrats Pursue Wrong Policies to Reduce Fires-They Should Do This. 2019. Available online: https://www.foxnews.com/opinion/jim-breslo-causing-california-wildfires (accessed on 30 November 2020).

61. David, N.G. Julia Louis-Dreyfus Fundraises for Anti-Trump Enviro Lobby Fighting to 'Ensure There's a Planet for the Next Generation'. 2019. Available online: https://www.breitbart.com/entertainment/2019/12/03/julia-louis-dreyfus-fundraisesfor-anti-trump-enviro-lobby-fighting-to-ensure-theres-a-planet-for-the-next-generation/ (accessed on 30 November 2020).

62. Huston, W.T. 'Young Sheldon' Star Iain Armitage Upset He Was too Young to Be Arrested at Jane Fonda's Climate Protest. 2019. Available online: https:/ / www.breitbart.com/entertainment/2019/12/06/iain-armitage-upset-he-was-too-young-tobe-arrested-at-jane-fonda-climate-protest/ (accessed on 30 November 2020).

63. Kew, B. Watch: Steve Harvey Rolls His Eyes after Reading Climate Change Question at Miss Universe Pageant. 2019. Available online: https:/ / www.breitbart.com/entertainment/2019/12/09/steve-harvey-rolls-his-eyes-after-reading-climate-changequestion-at-miss-universe-pageant/ (accessed on 30 November 2020).

64. Binder, J. Self-Declared Climate Change 'Global Leader' Mike Bloomberg Enjoys His Own Fleet of Private Jets, Helicopters. 2019. Available online: https:/ /www.breitbart.com/politics/2019/12/04/self-declared-climate-change-global-leader-mikebloomberg-enjoys-his-own-fleet-of-private-jets-helicopters / (accessed on 30 November 2020).

65. Delingpole, J. Delingpole: From Hitler and Stalin to Greta Thunberg-Time Loves to Celebrate Totalitarian Icons. 2019. Available online: https: / / www.breitbart.com/politics /2019/12/11/hitler-stalin-greta-thunberg-times-totalitarian-icons / (accessed on 30 November 2020).

66. Delingpole, J. Watch-Delingpole: Green Policies Are Turning Chile into Venezuela. 2019. Available online: https: / /www.breitbart.com/europe/2019/12/04/green-policies-are-turning-chile-into-venezuela/?utm_source=feedburner\&utm_ medium=feed\&utm_campaign=Feed\%3A+breitbart+\%28Breitbart+News\%29 (accessed on 30 November 2020).

67. Delingpole, J. Delingpole: Britain's Political Class Has Surrendered to the Green Blob. 2019. Available online: https://www. breitbart.com/europe/2019/12/09/britain-surrenders-to-the-green-blob/ (accessed on 30 November 2020).

68. Williams, D.U.N. Blames Climate Change for Global Mass Migration. 2019. Available online: https://www.breitbart.com/ environment/2019/12/02/u-n-blames-climate-change-for-global-mass-migration/ (accessed on 30 November 2020).

69. Zambuko, C. Climate Issues and Facts: Zimbabwe; Zimbabwe Meteorological Services Department: Harare, Zimbabwe, 2011.

70. Goklany, I. Wealth and Safety: The Amazing Decline in Deaths from Extreme Weather in an Era of Global Warming, 1900-2010; Reason Foundation: Los Angeles, CA, USA, 2013.

71. Stewart, J. How Broccoli Landed on Supreme Court Menu; The New York Times: New York, NY, USA, 2012.

72. Schulze, H.; Mauk, M.; Linde, J. How Populism and Polarization Affect Europe's Liberal Democracies. Politics Gov. 2020, 8, 1-5. [CrossRef]

73. Kommenda, N.; Voce, A.; Hulley-Jones, F.; Leach, A.; Clarke, S. US Election Results 2020: Joe Biden's Defeat of Donald Trump. 2020. Available online: https://www.theguardian.com/us-news/ng-interactive/2020/dec/08/us-election-results-2020-joebiden-defeats-donald-trump-to-win-presidency (accessed on 10 January 2021).

74. Mekelburg, M. Here's How Joe Biden's Climate Plan Could Affect the Oil and Gas Industry in Texas; Austin American-Statesman: Austin, TX, USA, 2021.

75. Abnett, K. World Welcomes U.S. Return to Paris Climate Accord, Readies Wish-List for Biden; Reuters: London, UK, 2021.

76. Leatherby, L.; Ray, A.; Singhvi, A.; Triebert, C.; Watkins, D.; Willis, H. How a Presidential Rally Turned into a Capitol Rampage; The New York Times Company: New York, NY, USA, 2021.

77. The Guardian. Capitol Attack: The Five People Who Died. 2021. Available online: https://www.theguardian.com/us-news/20 21/jan/08/capitol-attack-police-officer-five-deaths (accessed on 10 January 2021). 